\title{
Zulu Poems of (and for) Nature: Bhekinkosi Ntuli's Environmental Imagination in Imvunge Yemvelo (1972)
}

\author{
Oliver Nyambi $\odot$ and Patricks Voua Otomo
}

\begin{abstract}
Nature, climate crisis, and the Anthropocene have carved space in recent inter-, cross-, and multi-disciplinary humanities studies. In South Africa, such studies have barely touched literature in African languages. Nyambi and Otomo focus on the tropes of "lady nature," nostalgia, and dystopia in Zulu writer Bhekinkosi Ntuli's Imvunge Yemvelo to explore the complex ways in which these tropes test the normative epistemes of ecological crises. Beyond rejecting imperial distortions of indigenous environmentalism, Ntuli's poems re-center local knowledge of nature in understanding its relationship with humans. That knowledge subverts epistemic structures of colonial conservation, revising and re-visioning racially geo-politicized knowledge hierarchies.
\end{abstract}

Résumé: La nature, la crise climatique et l'anthropocène ont accru l'espace dans les récentes études inter-, trans- et multidisciplinaires des sciences humaines. En Afrique du Sud, ces études ont à peine touché à la littérature en langues africaines. Nyambi et Otomo se concentrent sur les tropes de la "dame nature", la nostalgie et la dystopie dans le texte Imvunge Yemvelo de l'écrivain zoulou Bhekinkosi Ntuli pour explorer les manières complexes dont ces tropes mettent à l'épreuve les épistèmes normatifs des

African Studies Review, Volume 64, Number 3 (September 2021), pp. 547-568

Oliver Nyambi lectures in the Department of English at the University of the Free State in South Africa. He is currently an Alexander von Humboldt Fellow hosted by Susan Arndt in the Department of English and Anglophone Literatures at Bayreuth University in Germany. E-mail: NyambiO@ufs.ac.za

Patricks Voua Otomo is a Senior Lecturer in the Department of Zoology and Entomology at the University of the Free State. E-mail: OtomoPV@ufs.ac.za

(C) The Author(s), 2021. Published by Cambridge University Press on behalf of the African Studies Association. This is an Open Access article, distributed under the terms of the Creative Commons Attribution licence (https://creativecommons.org/ licenses/by/4.0/), which permits unrestricted re-use, distribution, and reproduction in any medium, provided the original work is properly cited.

doi:10.1017/asr.2020.135 
crises écologiques. Au-delà du rejet des distorsions impériales de l'environnementalisme indigène, les poèmes de Ntuli recentrent la connaissance locale de la nature dans la compréhension de sa relation avec les être humains. Ce savoir subvertit les structures épistémiques de la conservation coloniale, en révisant et en remettant en question les hiérarchies de savoirs géopolitiques et racistes.

Resumo: A natureza, a crise climática e o Antropoceno têm marcado presença em recentes estudos inter e multidisciplinares na área das humanidades. Na África do Sul, estes estudos quase não abordaram a literatura em línguas africanas. Nyambi e Otomo centram este artigo nos tropos da "mãe natureza" ("lady nature"), da nostalgia e da distopia na obra Imvunge Yemvelo, do escritor zulu Bhekinkosi Ntuli, para analisar os modos complexos segundo os quais estes tropos põem à prova as epistemes normativas das crises ecológicas. Além de rejeitarem as distorções imperialistas do ambientalismo indígena, os poemas de Ntuli recentram o conhecimento local da natureza na compreensão da sua relação com os humanos. Esse conhecimento subverte as estruturas epistémicas da conservação colonial, revendo e revisitando as hierarquias de conhecimento racialmente geopolitizadas.

Keywords: Zulu culture; Anthropocene; anthropogenic crisis; indigenous languages; green imperialism; postcolonialism

\section{Introduction}

In the prevailing rush to (re-)center the humanities in discussions and debates about the environment, climate change, and the Anthropocene, it is critical to avoid sweeping generalizations, for instance, about what cultural perspectives of human-nature relations can reveal about the environmental future. Despite the generally agreed common human effects of environmental changes (Braun 2008; Goudie 2018; Govorushko 2012), for now and until the environmental Armageddon, humanity will continue to experience the effects of environmental alterations in unequal measures; this is particularly true for the negative effects. In the same vein, for now, humanity will continue to think and feel about (and act on) the environment as dictated by attitudes, beliefs, and notions of the environment that are shaped by humans' inherently eccentric spatial temporalities. In this light, what is meant by "the environment" and perceptions and conceptions of its harm and/or protection necessarily differ (Murdoch \& Marsden 1995). This difference constitutes one of the most important sources of global quarrels, particularly about the state of global warming and the human factor in it, and also, as we have seen in recent American politics under the presidency of Donald Trump, the very question of whether or not global warming is happening at all. In this context, this study aims to disentangle knowledge of the environment from realms of African, South African, and sub-Saharan African national categories and focus it on a particular culture-Zulu-to discover what new perspectives of the environmental present this culture offers. Estimated to 
number around twenty million, Zulu people easily constitute the largest ethnic group in South Africa (Carton, Laband, \& Sithole 2008). Now scattered across South Africa, Zulu people mainly inhabit the province of KwaZulu-Natal; they are well known for their rich cultural traditions, art, and warfare. Their monarchy is often dated back to King Shaka kaSenzangakhona, who is famed for his military prowess and statecraft. In this article, we use the term "Zulu culture" broadly to refer to various forms of customs, traditions, ideas, language use, behaviors, beliefs, arts, and other manifestations of self-expression by Zulu people.

Our choice of Zulu culture is not informed by any pre-existing ideas about its supposedly superior status in relation to other cultures in South Africa. Rather, the study is part of a broader project that re-situates the category of "culture" (especially as socially circumscribed by ethnic and linguistic "society"), to discover how its various manifestations can be seen as revealing new ways of understanding human-environmental and human-nonhuman relations at given times in the history of societies. Therefore, it makes sense that this study uses as a focal writer Bhekinkosi Ntuli, who is one of the earliest published poets in the isiZulu language and also a critic of literature in isiZulu. Ntuli is well known for the local and indigenous flair of his style and aesthetics steeped in Zulu oral traditions, customs, knowledge, and spirituality. In a speech at the Congress of the Afrikaans Writers' Guild where he protested the marginalization of Zulu literature, Ntuli argued the case for writers using the isiZulu medium to be inspired technically and aesthetically by narrative and knowledge traditions in spaces and times they occupy. Having warned that "it does not mean that the mere use of traditional devices will elevate any uninspired nonsense into good literature," Ntuli (1979:13) agrees with "many critics (who) have suggested that a writer should use the technique of his [or her] traditional literature as much as possible." In this light, we conceptualize Imvunge Yemvelo as a complex manifestation of locally-grounded ecological knowledge inspired by Zulu traditions of knowledge and expression.

This article and its conceptual framework relate and respond to the pervasive subordination of African knowledge, particularly in matters of environmental conservation. This is despite the widely available evidence in agelong traditions that demonstrate conscious efforts in African communities to think about ways of sustaining the ecological balance. Scholars such as William Slaymaker (2001) and Rob Nixon (2005) have contended that the marginality of environmentalisms of the Global South could be explained by the fact that ecocriticism had initially been seen as a Western literary exercise, which informed, especially in black African writers, complex forms of mistrust that led to what Slaymaker (2001) calls "ecohesitation." According to Cajetan Iheka (2018), ecocriticism first took root in the United States, where authors such as William Cronon (1983) initially linked it to a deceptive effort to preserve the wild by rounding up and moving onto reservations the first inhabitants of these lands. Iheka (2018) further shows, through Chinua Achebe's Arrow of God (1964), Wangari Maathai's Unbowed (2008), and the works of other African writers, that Africans have always had, in their local knowledge systems, 
efficacious methods of environmental protection. Similarly, Emily McGiffin (2019) states, in relation to indigenous peoples of South Africa, that local knowledge has sustained local ecological relationships between humans and nature, and that this ecosystem has suffered enormous destabilizations with imperial changes in land-use. In Of Land, Bones and Money: Toward a South African Ecopoetics, McGiffin (2019) argues that such drastic landscape alterations and reduction in fauna are owed mainly to the superior killing power of the settlers. She asserts that these and other socioeconomic alterations that are more profound and which culminated in apartheid policies are documented by the iimbongi, the oral poets of the Xhosa people of South Africa. Similarly, in her essay discussing "natures of Africa: ecocriticism and animal studies in contemporary cultural forms," Julia Martin (2017) justifies the need for exploring marginalized writings on African relations with the nonhuman world. She claims that these are necessary because "mainstream" scholarship often neglects to present the political and social dimension of the current eco-crisis in the African context. Therefore, in Natures of Africa, writers from East, West, and Southern Africa join voices using local oral traditions, novels, and songs to demonstrate that, because of its inherent social and political dimensions in Africa, ecocriticism is much more than a mere literary discipline. In Different Shades of Green, Bryon Caminero-Santangelo (2016) signalled a seizing of control of the discourse on African environmental issues and perceptions by African authors; this discourse previously had been dictated largely by the West.

As hinted above, much has been written in general about the interface between culture and the environment as part of a larger discourse and discipline of ecocriticism. Nevertheless, these studies mainly nibble at the local to make grand claims about culture and the environment at much larger social structures. For instance, in publications such as Scott Slovic and associates' (2015) edited volume Ecocriticism of the Global South, Graham Huggan and Helen Tiffin's (2010) Postcolonial Ecocriticism: Literature, Animals, Environment, and Bryon Caminero-Santangelo and Garth Myers's (2011) Environment at the Margins: Literary and Environmental Studies in Africa, Africa, the "global south," and the "postcolonial" environment are stressed in ways that de-stress the local in comprehensions of the eccentricity of cultures of knowing the environment. More "localized" studies such as Anthony Vital's (2005) "Situating Ecology in Recent South African Fiction: J.M. Coetzee's The Lives of Animals and Zakes Mda's The Heart of Redness" have focused almost exclusively on writers who write in the English medium, leaving indigenous-language literatures virtually untouched. Focusing on D.B.Z. Ntuli's (1972) poetry collection Imvunge Yemvelo, this study explores the theme of the environment, paying particular attention to the ways in which notions of the human-environment relations are constructed through specific cultural environmental aesthetics. This article examines how aspects of artistic discursivity in Imvunge Yemvelo create a discourse of human-nature interface that can be read in the context of ongoing discourses on decolonizing conservation as potentially and 
aesthetically mediating new environmental knowledge nurtured in Zulu culture.

Perhaps nowhere else is the importance of studying indigenous environmental knowledge systems clearer than in discourses on what Grove (1995:1) has called "green imperialism." This discourse dictates that our reading of Ntuli's ecocentrism in Imvunge Yemvelo center its agency, method, and ideology in the environmental politics of his time. These politics are driven fundamentally by colonialism and, therefore, linked to the imperial weaponization of knowledge, including ecological knowledge. Caminero-Santangelo (2014) has succinctly described the political nature of green imperialism, particularly how its dichotomization of European and African ecological knowledge, or rather its affirmation of the former and debasement of the latter, was part of the grand, extractive plan of colonialism. Writing specifically about the environmental politics of the colonial conservation park in his book, aptly titled Different Shades of Green: African Literature, Environmental Justice, and Political Ecology, Caminero-Santangelo (2016:4) observes the systematic exclusion of Africans (both physically and ideologically) from ideas and practices of ecological protection that veil "foreign economic interests" in the tourist conservation park as commitment to saving Africa's "exotic biodiversity and charismatic megafauna." Caminero-Santangelo links the strategic "erasure" of the local population and knowledge to colonial apologias and justifications, as he writes:

\begin{abstract}
Such exclusion is tied to a narrative portraying Africans as lacking the proper environmental sensibility and knowledge to take care of precious biodiversity hot spots and, more generally, suggesting that environmentalist effort in Africa needs to be conceived and led by non-Africans ... Such wisdom celebrates Western environmental knowledge and denigrates indigenous environmental practice, suggesting that Africans do not understand and abuse their environment and that Western experts (or Africans guided by such experts) need to protect it. (2016:4)
\end{abstract}

In the light of our focus on the postcoloniality of Ntuli's environmentalist agency-his self-inscription into the discourse of environmental knowledge - perhaps the most critical takeaway from Caminero-Santangelo's (2016) characterization of the duplicity of imperial conservationism above is the racialization, politicization, and "economization" of knowledge. What Caminero-Santangelo (2016) calls "the limitations of imperialist, marginalizing representations of African environments and environmentalism" (2016:14) have been exposed significantly in ecopoetical inquiries that reveal conservationist philosophies in such indigenous cultural belief systems and practices as riddles, totems, and taboos (Chemhuru \& Masaka 2010).

Similarly, many studies on the didacticism of African oral cultures have highlighted the conservationist thrust of indigenous knowledge transmitted orally through moral fables, myths, and legends. Such studies have noted how the transgenerational survival of these oral cultures has helped to conserve 
species and maintain ecological sustainability (Cloete 2009; Mudimbé 1991). Using an onomastic approach, Adrian Koopman, in his book Zulu Plant Names (2015), for instance, notes how plant names in Zulu culture functioned as repositories of indigenous knowledge about the plants' medicinal properties as well as their value as held by the society. This is contrary to Eurocentric, imperially chartered approaches that, in their (strategically) limited methods of knowing the social function of African onomastic systems, cosmologies, and epistemologies, conveniently ignored the environmentalism of plant and animal names, avoidances, and prohibitions in African totems and taboos. Dismissing the deterrences as doing nothing more than "designat [ing] ... what is forbidden on magical grounds" - to use Raum's (1973:3) exact words-such prejudiced approaches to African environmentalism reinforced what Elsie Cloete (2009:50) has called "the unproblematized adoption of the west's [sic] systems of knowledge, ethics and beliefs in terms of its notions of race and conservation space knowledges." The intersection between race, conservation, and knowledge is a critical site to read existential, temporal, and ideological factors informing both the "need" for colonial denigration of African conservationism and the kind of urge we see in postcolonial African literature such as Ntuli's poetry to challenge colonial environmental epistemes and knowledges discursively. This is not least because during Ntuli's time of writing, race (perhaps the major colonially imposed determinant of civilization and, therefore, intellect/knowledge) was embroiled in colonial methods of green imperialism.

Besides the "slow violence" manifest in colonized people's "environmentalism of the poor" (Nixon 2005:1), green imperialism, as Grove (1995) notes, involves the systematic alienation of the colonized and their knowledge from the land and its nature / environment, as well as philosophies about its care. This means that, of necessity, part of the process of decolonization would involve the desire within the colonized for reconciling with land and with it, nature, the environment, and indigenous knowledges of conservation. This desire is much akin to the postcolonial "empire-writing-back-to-thecentre" impulse of Ngugi wa Thiongo's (1993:1) concept of "moving the centre" as well as Achebe's (1989:40) commitment to instil in the African psyche the understanding that "their past—with all its imperfections—was not one long night of savagery from which the first Europeans acting on God's behalf delivered them."

\section{"Lady nature" and the Beauty of Conservation}

In Imvunge Yemvelo, Ntuli confronts green imperialism through a subtle counter-discourse that simultaneously exposes the shaky epistemes of colonial environmentalism and restores the conservationism of indigenous knowledge. However, beyond "moving the centre" in environmental knowledge production-that is, unveiling the colonial weaponization of conservation and highlighting the efficacy of local knowledge in environmental care-Ntuli's poetry goes further to reveal the material and spiritual 
entanglement between African humanity and nature. Transgressing previous constructions of this entanglement, in imperial discourse, as attesting to the African's incapacity for "development," Ntuli re-imagines the human-nature connection as a mechanism of ecological sustainability. In a style that the Kenyan film-maker Kahiu would use many years later in her Afrofuturistic film on the Anthropocene (Pumzi), Ntuli humanizes nature as a way of aestheticizing it and human attitudes toward (and relationships with) it. Besides his animation of nature as singing birds in the title Imvunge Yemvelo (meaning "the humming sounds of nature"), Ntuli constructs the humannature connection by metaphorically equalizing nature with humans.

Unlike in Kahiu's man-nature typology, where the protagonist in her magical realist illustration of the importance of environmental conservation sacrifices herself to make her decomposing body the nourishment for the "human-tree" of life, Ntuli anthropomorphizes nature by personifying it as a beautiful lady. Leitmotifs of admiration, attraction, importance, and fragility evoke the "lady-nature" as crucial to the male persona's life and susceptible to his harm. The aesthetic function of this metaphorical allusion can be understood best in the context of its patriarchal configurations. In a patriarchal culture where women are identified as the "weaker sex," their protection is delegated, as a gendered responsibility, to men. It is important to note here that the feminization of nature by a male author and/or persona can be problematic. Feminized images depicting the fragility and vulnerability of nature to male (ab)use create impressions of gendered agency. Femininity is objectified to be enjoyed by the male persona through a not-so-subtle hierarchization of the agency of becoming and being. The beauty of nature and, indeed, life itself, exists at the mercy of male power and his gaze. This potential implication of the gendered construction of human-nature relations contains unsavory echoes of its sexualization and eroticization by the Western colonial explorer. Sambit Panigrahi's (2015) reading of Joseph Conrad's (1955) An Outcast of the Islands reveals how masculinist local and imperial forces ganged up against feminized nature as a mechanism of naturalizing exploitative vertical relations that hierarchized the male colonialist, nature, landscape, and its (indigenous) inhabitants. Writing about the ocean and its feminization by the colonial sailor, Panigrahi argues:

Exemplifying the capitulation of the feminine sea before her master Tom Lingard, the narrator observes: '... womanlike, the sea served him humbly and let him bask unharmed in the sunshine of its terribly uncertain favour' (Conrad, Outcast 25). So, Nature, like woman, is validated as a subjugated and faithful servant of man as Linda Vance very rightly observes that 'both woman and nature have been controlled and manipulated to satisfy masculinist desires.' This also evokes a Baconian military fantasy of subduing the feminine Nature to man's dominion. Francis Bacon, the ideological father of Science, in a notorious remark of his, advises man to 'bind her [Nature] to ... [his] service and make her ... [his] slave.' (Panigrahi 2015:30) 
Metaphorically evoked as a beautiful lady, nature in Ntuli's patriarchal imagination acquires telling connotations of attractiveness, fragility, and charm, telling in the sense that these attributes aesthetically summon patriarchal configurations of agency, which designate to the male author the responsibility for protecting the lady and sustaining her beauty. The aesthetic dimension of this role designation concerns the "beauty" and/or "ugliness" of what can happen, depending on whether the role is either performed or the man is derelict on its discharge. The themes of "lady nature," nature's beauty, and susceptibility are thus interlinked, to foreground the motif of protection. We see this, for instance, in the poem Lomfuzana, in which Ntuli writes:

Ngibheka ngakubona uyisiphalaphala...

Uyiqepheqephe lesikheshekheshe

Amehlo ami sengathi akuluma amanga

Uma engikhombisa lomfunzana phansi

Kulele amagqinsi amafu emehlweni...

Ngumqondo ocwebile, nomtshingo oligagu

Okusakuxhuma nalokhuyakuqhakaza

Wawugeleza umfula, manje yisiziba

Iphelele kuso imifudlana yempilo

Yenze isithako esiyikhambi $(1972: 7)$

(Translation)

I look at you and see how beautiful you are

You are gorgeous and fit

You are attractive and appealing

I cannot believe my eyes

When they show me such beauty

Your eyes are covered in clouds

You have a clear mind and a legendary appearance

You compliment the older beauty

You were a running river

But now you are just a pool

Where all rivers united

Combining a herb that heals

There are two aesthetically complementary forms of conceptual metaphors in this quotation. These metaphors map symbolic characteristics of nature that not only describe its worth but more importantly (in the light of the present focus on conservation), engender its beauty in a way that reflects the "beauty" of its protection. The first metaphor is implied in the poet's reference to nature as a beautiful lady. Besides the beauty, attraction, and fragility of nature mapped by the imagined lady as the metaphor's source domain, her seductiveness and the speaker's weakness for it suggest the 
agential dimension to her beauty in causing the viewer to care. Her beauty is depicted as enchanting. Its seductive lure spellbinds the writer and creates implicit sexual innuendos that conjure associations of affection, closeness, connection, and the probability of their union and procreation. Unlike the usual metaphorical configuration of "mother nature," which invokes gendered connotations of the procreative mother figure to foreground nature's care for (and sometimes wrath against) humanity, Ntuli's "lady nature" serves the viewer only to the extent that he serves her. This means that her availability is dependent on certain actions the speaker has to take to sustain her beauty. This brings us to the second conceptual metaphor: NATURE = RIVER.

Like the first one, this metaphor is conceptual. That is, it deploys image schemas related to a concrete concept (the river) to characterize and explain a more abstract concept - the "nature" of nature. This invocation of a known source domain and the inscription of its popular correspondences or "senses" onto the target domain (nature) create mind maps and cognitive biases that compel the re-routing of the knowledge of the nature of rivers to the "nature" of nature. However, as Zoltan Kovecses (2010:14) notes in a general context, beyond the semantic and discursive functions of cognitive mappings, our "metaphorical competences" thrive in contexts. That is to say, the potential of Ntuli's metaphorical mappings to function as "sites and media of knowledge transfer" (Hallyn 2013:211) is dependent upon their situation in Zulu belief systems about the role and significance of nature, particularly rivers. The tripartite themes of beauty, nature, and maidenhood in Ntuli's poem have an enduring history of convergence in Zulu culture. Perhaps nowhere else is this convergence more dramatically displayed than in the famous annual Umhlanga ceremony, "whereby maidens or unmarried girls gather at the royal capital to cut reeds to rebuild the tohonco or royal kraals, to honour and pay homage to the Queen Mother (indlovukazi)" (Sone 2010:134). The description of the role of the reed (beyond its ornamental function) by the provincial KwaZulu-Natal Culture Department on its website clearly reveals the connection between maidenhood, culture, and nature:

Each maiden carries a reed which has been cut by the riverbed. It symbolizes the power that is vested in nature. The reeds reflect a deep mythical connection with the origins of the Zulu people where, tradition tells us, the original ancestor emerged from a reed bed. In everyday use, these reeds are the building material for the typical domed or beehive hut, iqhugwane, which is found particularly in rural homesteads throughout KwaZulu-Natal. Zulu mythology has it that if a young woman who is not a virgin takes part in the reed dance ceremony, her reed will break and embarrass her in full public view. (Zulu, n.d.)

The conceptual connection of maidenhood with reeds and the riverbed echoes Ntuli's metaphorization of the beautiful woman as nature, and of nature as a river. Nature (the reed) in the Umhlanga ceremony defines the maidens' attractiveness. It (nature as symbolized by the intact reed) 
symbolizes the maidens' virginity and "naturality," while the broken reed represents the loss of maidenhood. In the poem Lomfuzana, the flowing river is not only symbolic of the object of the persona's attraction; that is, thriving nature, its unbrokenness, and beauty. Perhaps more importantly, it is also the conceptual source domain that Ntuli uses to map image schemas explaining the desirability of healthy nature. In this conceptual sense, the river is loveable, hence the proclamation "I love this river/I need this river.../I will tie it on my shoulders." The health of the river-symbolized by its flowing - is linked to the persona's own health through the "herb that heals," which it nourishes. Thus, the persona's love for the river is a statement of appreciating its gift of the "herb that heals"; hence, his avowing that "I love this place/I learnt from it to love/To love the art of herbs." In this sense, a broken river (unlike a broken reed in the Umhlanga reed dance) is not only a site of shame but also a threat to the speaker's health-a threat that underlies the conservation theme of the poem, as the speaker warns, "Do not start the heat/If water heats where would I swim?/You want to mute my song/The beat of my soul." In imagining the river as a song of which the decibels sustain the "beat of [his] soul," the speaker effectively ties his welfare to that of the river. This allows him to share the pain of the river when it eventually loses its flow due to the heat ("You were a running river/now you are a just a pool"), especially because with the loss of the river comes the death of "the herb that heals."

\section{"Intokozo yayizolo": ${ }^{1}$ The Nostalgic Imagination in Ntuli’s Poetry}

In his analysis of Ntuli's "love and appreciation of nature," Anthony Mlondo (1994:104) notes how Ntuli's attachment to nature leads him to pine for the environmental vibrancy of spring and summer, even though the seasons are interrupted by winter only temporally. In Ntuli's treatment of the theme of seasonal cycles in Impilo eyayilahlekile isizuziwe ("Life previously lost is regained"), Mlondo (1994:104) highlights the dependence of humans on nature for their happiness. For Mlondo, Ntuli as the speaker shows "dissatisfaction because of the poor condition of nature and its inhabitants in winter." However, winter is only transient, which means that the "harm" it inflicts on the exuberance of nature (and humanity) passes. In Imvunge Yemvelo, much of Ntuli's pathos is evoked by a sense of unrestored harm to nature. A related thematic strand in his poems concerns his "dissatisfaction" with human attitudes toward nature spurred by modernity. The extent and meaning of this "dissatisfaction" is reflected in his unmistakable nostalgic environmental imagination. In his poetry, nostalgia implies and implicates times, spaces, humans, and their complex intersections and interactions in the destruction of the environment.

Nostalgia, as we conceptualize it here, is not merely restorative, in the sense provided by Jennifer Ladino (2004:90) when she argues that "restorative nostalgia, linked with 'nostos,' poses as truth, embraces tradition, and seeks a reconstruction of the lost 'home,' imagined as a return to a coherent origin." Rather, our notion of nostalgia is much akin to Andreea Deciu 
Ritivoi's concept of it as "signal[ing] the breech [between past and present] (in ways that) inaugurate a search for the remedy" (quoted in Ladino [2004:90]). In the poem "Lomfuzana," we have already seen how the past, which is associated with naturality, the thriving river, and the "herb that heals," becomes the object of the speaker's fond reminisces. Contrastingly, the fond memories are invoked in the present, where the "heat" has caused the river to dry up, sucking the life out of the life-giving "herb that heals." According to Jennifer Delisle (2006:388), "Nostalgia is neither negligent nor apolitical. Ntuli's nostalgic reminisces of the desirable past can be read as allegorically alluding to the precolonial period, and the dried-up river and wilted "herb" as symbolizing the insufferability of colonialism. It is easy to understand why the politics of his environmental nostalgia could not be more explicit. Writing under Apartheid, Ntuli, like many of his contemporaries, among them Mazisi Kunene, Lewis Nkosi, and Mafika Gwala, were censored for political correctness, ideologically and aesthetically. As Russell H. Kaschula (2003:63) notes, "The thematic repertoire of the[ir] creative works remained controlled, not by missionaries, but by apartheid authorities and the controlling language boards which insisted on material which was politically and socially neutral."

The notion of nostalgia reflected here relates to the environmental pedagogics of the longed-for ecological past. It is informed by what Dennis Walder calls "postcolonial nostalgia-a style of historicizing that commands an ethical engagement with the past by connecting what you remember with the memories of others, colonizers and colonized and in-between" (cited in Van Houwelingen [2012:94]). Perhaps the most crucial aspect of the postcoloniality of this form of nostalgia is its ethical dimension-its reflective implication of conflicting memories of the past in its discursive construction of which pasts should carry environmental lessons for today. Writing in the context of Apartheid South Africa and particularly about Mhlophe's 1986 play Have You Seen Zandile?, Delisle (2006:395) argues that "nostalgia is located at the junction between the individual psyche and cultural symbols ... [that] nostalgia looks to the future ... as much as it looks to the past." In this sense, Walder's (cited in Van Houwelingen 2012) notion of ethics and how its discursivity is established by purposeful memorial sojourns into the past reveals the inherently political nature of nostalgia and how it may be politicized as "nostalgic counter-discourse" (Delisle 2006:387).

Ethics in Walder's (cited in Van Houwelingen 2012) notion of postcolonial nostalgia implies the discursive aestheticization of temporalities and relationalities. That is, the past becomes good or desirable in terms of and in relation to the dystopia of the present. Kevis Goodman (2008:195) reflects on the historical trajectory of the phenomenon leading to the Romantic era. He explores the intricate relationship between earlier science-based notions of nostalgia and its human sides in Romantic literature. Critical in Goodman's (2008) study vis-à-vis the interest of the present study of Ntuli's postcolonial nostalgia is his observation of subtle continuities and metamorphoses of scientific nostalgia in contemporary forms of nostalgia. Our focus on scientific nostalgia is not in any 
way meant to imply that Ntuli was aware of "scientific nostalgia" and that he consciously deployed it in his poetry to reinforce his notions of the "teaching" potentialities of the environmental past. Rather, what we seek to do is to cull from Goodman's (2008) delineation of the psychology of nostalgia certain aspects of its nature that make it a convenient site for establishing the environmental "lessons" of the past as the solution to the problematic relationship of humanity with nature in the present.

A better way to conceptualize the notion of scientific nostalgia with respect to the environmental "ethics" of the past is to consider its origins closely. We situate Goodman's (2008) account of the origins of the concept in the medical field to demonstrate what aspects of its early forms we invoke to read Ntuli's aesthetic deployment of nostalgia in his subtle attack of colonialism through its modern manifestation in environmental harm. One important parallel can be discerned in the relationship between scientific nostalgia and Ntuli's own nostalgia in Imvunge Yemvelo. Scientific nostalgia concerns the construction of nostalgia as a disease and its portrayal in Ntuli's poetry as a direct consequence of human minds sickened by the destruction of nature by humanity. Here is an account of the emergence of nostalgia in the medical field:

Having made its debut in medical texts, it signified a disease, specifically a disability of wartime and colonial mobility, a somatic revolt against forced travel, depopulation, emigration, and other forms of transience. Coined at the end of the seventeenth century by a Swiss physician, Johannes Hofer, the term described a dangerous and frequently fatal wasting illness among soldiers, sailors, and others forced to leave their homes permanently or temporarily. (Goodman 2008:201)

In this description, among other things, nostalgia is the fear of apartness from home. Movement from home is portrayed as the cause or catalyst for the ailment, thus suggesting that staying at home is the antidote or precautionary measure for dealing with nostalgia. The fact that nostalgia in its extreme condition could lead its victims to choose to kill themselves rather than face the pain of missing home suggests a deep connection to home in a way that makes it a physiological part of the victim. Thus, life is endangered when circumstances demand that people leave their homes. For the soldiers and sailors who chose to lose their lives as opposed to suffering the pain of nostalgia, the loss of home was an overpowering force that invalidated the meaning of life outside what home had inscribed on its true nature. It is possible that, as David Coplan (1995) noted in his study of sung oral poetry by migrant Basotho miners in South Africa, Ntuli's nostalgia was influenced by movements of African labor to urban areas and the disruptive effects it had on the traditional way of life.

What Alastair Bonnett (2015:1) calls "the power of loss" in "modern sentimental nostalgia" (Goodman 2008:201) urged soldiers to fall on their bayonets and sailors to dive into the seas at the realization that they might never return home. Thus, in actual fact, "[t] he power of loss," which informs 
the loss of life, reflects the power of the desire for a return. That is to say, it is the consuming power of longing for a return home that redefines living or good health as bound up with home. This notion of nostalgia pervades Ntuli's environmental imagination in unique ways, gesturing to a different conception of the "pastness" of the past in the environmental present. "Home" in Ntuli's poems is evoked as a time that time has distanced from the writer, hence, making it his object of nostalgic longing. However, in the poems, home is not just a time in the past of which the idyllic pastness informs its longing in the present. Rather, home is the past when time still bound the speaker and nature together. This idealized "home" is disbanded by time, causing the speaker to move, alone, into a bereft future while home-a time of oneness with nature-remains behind. Humanity is portrayed as the cause of the fixation and "reluctance" of nature to move into the future. The temporal separation between the speaker and home/nature becomes the metaphorical pathogen that causes his nostalgia.

The poem "Intokozo yayizolo" ("Yesterday's Happiness") best illustrates how, in Ntuli's poetry, nostalgia is linked to the past as the archetypical home, defined as such by the perfect co-existence between nature and humanity. The intense feeling of nostalgia in the poem is both a reflection of the extent of the breakdown of the speaker's previous relationship with home and nature, and also a subtle hint at what humanity can do to restore the past and consequently re-stablish man's respect for nature. The title of the poem gives early hints of its nostalgic effect. The title refers to "yesterday's happiness," where "yesterday" is used as a metaphor for the past. Locating happiness in a human-nature relationship in the past not only underscores its absence in the present, but also more importantly, foregrounds what made the past "happy" - that is, the symbiotic relationship between humans and nature. In the theoretical schema of nostalgia influenced by its scientific origins, the past in "Intokozo yayizolo" can be viewed as a sort of idyllic "home" whose happiness reflects the desirability of past relationships between nature and humankind. As in the "cover text" where nature is animated and embodied by singing birds, in this poem, nature is personified, this time as a beautiful lover whose best moments of love with the speaker are in the past. Understanding what worked in this love relationship in the past is evoked as the window to what can work for a similar relationship in the present, as the following citation shows:

Amehlo ami ahlangana nawe,

Ilanga lithushuka lixoshwa umnyama,

Ngase ngiliqephezela ngawe,

Lathi: "Halala!"

Izinyoni zeza ukusibungaza,

Zashaya ihlombe zagegetheka:

Izinyosi zeza zavungaza,

Zithi: "Halala!" (1972:23) 
(Translation)

My eyes come across you

The sun came out driving away the dark

And I embraced it through you

It said "halala"

The birds came to celebrate us

Clapped hands and laughed

Bees came in their numbers

Saying "halala"

I said goodbye to the sun with your name

I greeted the moon with your name

In this excerpt, motifs and symbols of nature are used to characterize the past in a way that makes the deviation of the present from it the source of humanity's unhappiness. In order best to establish the convenience of the past as the ecological blueprint for living in the present, it is imperative to identify the moment of the speaker's utterance, that is, to ask at what point the longing for the past is being expressed and what aspects of the temporality of this point trigger nostalgia. The moment is in the present, which is portrayed as disconnected from the past by certain symbolic signals and actions.

Perhaps the most significant marker reflecting the discontinuity between the good past and the bad present is the use of the exclamation "goodbye." This exclamation in itself does not identify anything worth missing in the past, that is, something that can trigger nostalgic sentiments in the speaker. However, read in the context of what is being left behind and its significance to the speaker's emotions, the exclamation reveals a passionate expression of trepidation at the separation. In the line "I said goodbye to the sun," the sun is the symbol of nature, whose time with the speaker is depicted as over. The symbolism aestheticizes the relationship. Thus, saying "goodbye to the sun" appeals to our sense of feeling as signifying loss - the loss of both light and warmth associated with the sun. This sense of loss is highlighted further by the superficial return of the lover in the form of the moon and the rekindling of the love "affair," which is symbolized by the speaker's love for the moon. However, this "return" of nature in the form of the moon is depicted as less glamorous and romantic. This is because nature's appeal in the eyes of the speaker has been dampened. This diminished appeal of nature to the speaker is reflected in the implied symbolism of the night in which the speaker "greet[s] the moon."

The past (symbolized by the sun) is portrayed as a moment of celebration, in which the speaker and nature embrace each other in a passionate, mutually beneficial relationship characterized by warmth and light. The same can be said about the aesthetic function of the sun in the poem Kukhokho $u$... (who lived in the year 970 A.D.), where the ancestor ( "ukhokho") is depicted as symbolizing a longed-for-past whose desirability is embodied by 
the glow of the sun: "In a hundred years/The sun was always on your eyes/ The moon was always on your eyes/Even the stars in the sky" (Ntuli 1972:9). In "Intokozo yayizolo," the "perfect" past is manifested in the mood in which the relationship between the speaker and nature is consummated. This mood is evoked in part by the celebratory chant "halala," which is repeated in the first two stanzas of the poem. Celebration implies an ideal moment when the speaker and his implicit lover (nature) live as victors over forces that might threaten their union. As a motif constituting the affectionate relationship, love signifies the necessity of commitment between the speaker and nature. The flourishing relationship between nature and the speaker in the past is sustained by a sense of obligation, which is reflected in the speaker's zeal for the protection of nature. Therefore, we find that in the poem, the speaking subject demonstrates his commitment to his lover (nature) by appreciating "her" beauty, as can be inferred from the act of passionate gazing: "My eyes come across you/The sun came out chasing away the dark/And I embraced it." Nature's acceptance of this outpouring of adoration is evoked through the complementary gestures of certain aspects of its parts. The bees and birds are "clapping," "laughing," and chanting "halala." These gestures of revelry endorse the thriving relationship between the speaker and nature.

Thus, in "Intokozo yayizolo," nostalgia as a form of "sickness" triggered by a temporal removal from an idyllic past does not merely signal melancholy for a past in which nature and humanity had a reciprocal connection. In fact, the nostalgic sickness manifesting in this poem is connected to the speaker's reluctant acceptance that nature has taken on a new negative attitude against humanity - an attitude that, as mentioned above, is reflected symbolically by the "setting" of the sun (nature) and its replacement by a dark and "cold" night as well as the dim moonlight. Yet, happiness is not only bound up with "yesterday" or the past, but more importantly, with a good relationship with nature that existed in the past. Thus, the nostalgic sickness for the past (home) in the poem reflects both the affectionate connection the speaker had with nature and also the happiness that this connection guaranteed. However, this nostalgic reminiscence of the past does not make its memory belong to the past. In fact, the memory of the past as remembered in the present in a nostalgic contemplation defines and characterizes the unhappiness of the present in terms of (and in comparison with) the happiness of the past. This view of the present in terms of the past projects past human behavior as imperative to achieving happiness in the present. As we have seen above, that behaviour is marked by the caring (and loving) of humanity for nature and the guaranteed reciprocity of the affection by nature.

\section{Ntuli's Dystopian Imagination in "Enyangeni"}

The environmental present in Ntuli's poetry is an anthropogenic crisis. This crisis is portrayed in the poems as a man-made entanglement reflecting humanity's narrow notions of progress and achievement. In his poems, humans have created an environmental crisis through their inventions of 
alternative "relationships" and sites of pleasure, especially technology, that harm nature. In the metaphor of the love relationship used in "Intokozo yayizolo," a marked departure or separation from "home" (the bliss of oneness with nature) is signified symbolically by humanity's new attractions and "relationships." In fact, as some of Ntuli's poems reveal, technology not only has replaced nature as the object of the adoration and affection of humanity, but also has "teamed up" with humans to destroy nature. Ntuli's personas in Imvunge Yemvelo are unwilling participants in humans' shift in affections. The personas are depicted as reluctant outsiders and non-believers, whose ambivalent perception of the present is informed by their existence in an in-between space between the dystopian present and a make-believe utopian past. For these personas, the crisis is not merely humanity's loss of favor with nature (the only sustainable site of happiness), but rather a sign of a pending apocalypse that awaits both humanity and its inventions.

Situated in a modern era characterized by forms of human development that are antithetical to nature, the speaker is frustrated by self-destructive human indulgence. He becomes a cynic whose "sickness" from nostalgia makes him repellent to the present and its ways of finding pleasure in things divorced from the happiness of the past. The poem "Enyangeni"illustrates this nostalgic dynamic and how it reflects the speaker's eccentric subjectivity vis-à-vis humanity's newest sites and technologies of happiness. The term "Enyangeni" denotes the "moon," the symbol of nature whose occupation by humanity in the poem reveals the untenability of humanity's new-found pleasure-that is, conquering nature.

As in "Intokozo yayizolo," "home" and homeliness in this poem exist in the past, where the knowledge of the world seamlessly passed through generations as a form of tradition. This is not to imply that traditions by their nature are fixated in the past. Rather, the speaker in "Enyangeni" suggests that his literal occupation of the present and mystic connection to the past create for him grounds for objective comparison of which aspects of the past and the present are worth taking into the future. In this poem, new traditions informed by the restlessly inventive side of human nature are portrayed as occluding and damaging the natural course of nature. Thus, while not intending to imply that change is mutable, the poem flags the fatality of the uncertainty of futuristic inventions, which increasingly becomes apparent when their unknown risks are compared with known and certified traditions, as the following excerpt from the poem reveals:

\footnotetext{
Nanso imihlolo webantu!

Cababa enyangeni umuntu!

Usecosha amatshana akhona!

Into engenziwanga sidalwa

Seloku konke kwadalwa

Ngomzuzwana usekhulile umuntu

Wawakhombisa amandla esintu
} 
Olwazi olungedlulwe yilutho.

Yonke indalo idumisa umuntu,

Yonke indalo ithobela isintu.

Uguya ngamandla, unqobe umkhathi

Owanqoba bonke ngaleziyazikhathi.

Manje uyena ungqongqoshe

Ongenakuthikanyezwa mthakathi.

Uchitha uju lwenjabulo phakathi.

Onke oamehlo abheke phezulu,

Yonke imilomo isholo phezulu:

"Bayohlala laphaya abantubehtu!"

Izandla zikhomba ngomdlandla phezulu,

Bonke bandizela ngokuphangelana phezulu

Zwana isililwana sosanyana phansi (1972:41)

(Translation)

My people

Humankind has landed on the moon

$\mathrm{He}$ is already picking little stones from there

Something that has never been done before

Ever since everything was created

In a short period of time, a person has grown

He has shown the power of mankind

Of knowledge that cannot be surpassed by anything

All creation praises mankind

All creation bows to mankind

The one who conquers all

He is now the minister

Who cannot be hampered, not even by a witch

He is flowing with the honey of happiness inside

All eyes are looking up

All voices raised up high "our children will stay up there"

With energy, hands are pointing up

Everyone is flying in a hurry

Hear the cry of an infant, down with it!

In this poem, two symbolic occurrences reflect the effect of futuristic inventions and the reaction of humanity to them. The first event is the moon landing, which is depicted as representative of the threats posed by human inventions. The moon landing is the beginning of a human project to colonize space so that "our children will stay up there." However, the children 
are not only disinterested in this newly discovered colony, but they are also in fact scared by it, hence the plea to "Hear the cry of an infant." Before we look at the symbolic side of the infant's cry in declining the offer to "stay up there," we need to unpack the symbolism of the moon landing. Besides the speaker's voice, which is reinforced by mystic dabbling in past and present milieus, tone is one of the key discursive elements in his reflections that establishes past practices of respect for nature as guaranteeing human happiness, especially in comparison with technological human inventions. In this view and in terms of the scientific notion of nostalgia outlined above, "home" is the place of safety in the past that is sheltered from the uncertainties of human inventions that destabilize the balance of the universe through colonizing space. The speaker's nostalgic sickness can be located in the cynical tone reflecting his skepticism of the space landing and its attendant symbolisms, as the following translated lines reveal:

My people/A person has landed on the moon/He is already picking little stones from there/Something that has never been done before/Ever since everything was created/In a minute a person has grown/He has shown the power of mankind/Of knowledge that cannot be surpassed by anything/All creation praises mankind/All creation bows to mankind/The one who conquers all.

Far from being an ode to futuristic human discoveries, these lines indicate the vanity of inventions, especially as replacements for what nature used to be, mean, and offer to humanity. There is certainly no hint that humanity cannot chart new traditions inspired by inventions and still continue on the path of old environmentally conscious traditions. However, for the speaker, old and new traditions are mutually exclusive, and the pursuit of one is necessarily the abandonment of the other. In this view, the speaker's characterization of man's landing on the moon as "something that has never been done before" does not depict the landing as a virtuous act of human achievement. Rather, the description covertly regrets the elision of traditions of the co-existence between humans and nature in the advent of these new preoccupations of humanity-machines. In the same vein, the characterization of humanity as "one who conquers all" does not necessarily celebrate the conquest of space. In fact, the reference to man's might is highlighted as spurred by his capacity for invention, which leads him to test traditions that were hitherto sacred and that guaranteed human happiness. The toxicity of this power is reflected not only in what it empowers humanity to do-that is, exploiting nature by colonizing the moon and "picking stones from there"but also in the tone of the voice that is describing the work and workings of man's might.

Tone uncovers the speaker's attitude toward man's might, his inventions, and the consequent new traditions of domination inspired by them. We can infer the speaker's attitude toward this power and its consequences, especially toward nature, in the ironic portrayal of humans' attitude toward other 
living and inanimate objects. In particular, man's moon landing is portrayed neither as beneficial, in any way, to sustaining the natural balance of the universe, nor as an innocuous visit paid for its own sake. In fact, as we learn at the beginning of the poem through the symbolic act of "picking stones from there" and later, through the speaker's distressed hint that "our children will stay up there," the mission to the moon is not a voyage of discovery. Rather, the mission constitutes the beginning of man's designs to dominate and exploit nature. Thus, when the speaker ironically refers to humanity as "[t] he one who conquers all," he is in fact furtively implying the fatalistic nature of the new abilities of humanity and the absence of checks to man's selfcentered innovations. Thus, to the speaker, the consequent obscurity about what man's innovation may potentially lead to constitutes the fallibility of man's might. In this sense, the imposing power of humans that deifies them in statements such as "[a]ll creation bows to mankind" can be read as ironically illuminating the point of weakness in the point of humanity's greatest strength, that is, innovation.

In "Enyangeni," tone is an aesthetic facet to the speaker's viewpoint and as such, a manifestation of his subjectivity. The speaker's nostalgia highlights fundamental schisms between the good past and the crisis-ridden present. His opening address to "my people" is tinged with a sense of authority that legitimates his prescription of what within the ambit of past and present rules of nature is within conventional human endeavor. What makes his characterization of man's self-destructive inventions nostalgic is not the mere fact that he has lost his influence to circumscribe the terms and conditions of human interactions with nature. Rather, the flair of resignation and regret is informed by his realization that human inventions fatally lack the necessary self-regulation to avert an unintended armageddon. In actuality, the speaker's concerns are being confirmed daily: Man-made climate change caused by humanity's unbridled use of might is rendering the planet inhospitable, with the result that the quest for other planets and the possibility of an exodus from earth have dominated recent scientific discourse (Billings 2018; Szocik et al. 2016). In this case, tone simultaneously constitutes and reflects the speaker's dystopian imagination. Here, nostalgic sickness does not entail a mere reflection of melancholy for the idiomatic "good old days." Rather, the memory of (and nostalgia for) "home" and the quest for a return to it is part of a personal defense mechanism informed by the speaker's fear of the future that the increasingly intricate human inventions are rendering unknown.

\section{Conclusion}

Perhaps a proper way to conclude a discussion of this nature is to return to the founding context informing the questions guiding the inquiry. What we originally set out to do was to locate and illustrate the environmental imagination in Ntuli's poetry collection Imvunge Yemvelo. The aim was to explore the ways in which Zulu poetry by Ntuli mediates indigenous 
environmentalism-to discursively re-situate it away from the margins where colonial epistemes have conveniently confined it. What becomes clear is the fact that beyond "moving the center" in global discourses about environmental conservation, Ntuli's poems reveal what such global discourse can gain in the urgent task of decolonizing environmental knowledge. Despite censorship and its use by the Apartheid regime to colonize and hegemonize knowledge, the conceptual metaphor, the symbolism of "lady nature," and allegories of nostalgic past homes all offered Ntuli subtle sites to nibble at the fundamentalist and racial essentialisms of imperial environmentalism. Analyses of the poems "Intokozo yayizolo" and "Enyangeni" not only flag the synonymity of the precolonial past with certain desirable human/nature interactions, but more importantly reflect on how the nostalgic memorialization of past traditions of happiness ("intokozo yayizolo") in the era of colonial modernity projects the past as a metaphorical home to which the present must relate and aspire to emulate.

\section{Acknowledgments}

The authors would like to acknowledge the generous funding received through the University of the Free State's Interdisciplinary Research Grant. Thanks are also due to Ms Nkosisiphile Zwane, who translated the poems used in this study, as well as to the Editors and anonymous peer reviews whose criticisms helped bring the best out of this study.

\section{References}

Achebe, Chinua. 1964. Arrow of God. London: Heinemann.

1989. Hopes and Impediments: Selected Essays. New York: Doubleday.

Billings, Linda. 2018. "From Earth to the universe: Life, Intelligence, and Evolution." Biological Theory 13 (2): 93-102.

Bonnett, Alastair. 2015. The Geography of Nostalgia: Global and Local Perspectives on Modernity and Loss. London: Routledge.

Braun, Bruce. 2008. "Towards a New Earth and a New Humanity: Nature, Ontology, Politics." In David Harvey: A Critical Reader, edited by Noel Castree and Derek Gregory, 103-24. Sussex: Wiley Blackwell.

Caminero-Santangelo, Bryon. 2014. Different Shades of Green: African Literature, Environmental Justice, and Political Ecology. Charlottesville: University of Virginia Press.

Caminero-Santangelo, Bryon, and Garth Myers. 2011. Environment at the Margins: Literary and Environmental Studies in Africa. Athens, Ohio: Ohio University Press.

Carton, Benedict, John Laband, and Jabulani Sithole. 2008. Zulu Identities: Being Zulu, Past and Present. Scottsville, RSA: University of KwaZulu-Natal Press.

Chemhuru, Munamato, and Dennis Masaka. 2010. "Taboos as Sources of Shona People's Environmental Ethics." Journal of Sustainable Development in Africa 12 (7): 121-33.

Cloete, Elsie. 2009. "Ecofutures in Africa: Jenny Robson's Savannah 2116 AD." Children's Literature in Education 40 (1): 46. 
Conrad, Joseph. 1955. An Outcast of the Islands. London: Collins.

Coplan, David. B. 1995. In the Time of Cannibals: The Word Music of South Africa's Basotho Migrants. Chicago: University of Chicago Press.

Cronon, William. 1983. Changes in the Land: Indians, Colonists, and the Ecology of New England. New York: Hill and Wang.

Delisle, Jennifer. 2006. "Finding the Future in the Past: Nostalgia and Communitybuilding in Mhlophe's Have You Seen Zandile?” Journal of Southern African Studies 32 (2): 387-401.

Goodman, Kevis. 2008. "Romantic Poetry and the Science of Nostalgia." In The Cambridge Companion to British Romantic Poetry, edited by M. McLane, 106-17. Cambridge: Cambridge University Press.

Goudie, Andrew. 2018. Human Impact on the Natural Environment: Past, Present and Future. Sussex: Wiley Blackwell.

Govorushko, Sergey M. 2012. Natural Processes and Human Impacts: Interactions between Humanity and the Environment. London: Springer.

Grove, Richard. 1995. Green Imperialism: ColonialExpansion, Tropical Island Edens and the Origins of Environmentalism, 1600-1860. Cambridge: Cambridge University Press.

Hallyn, Fernand. 2013. Metaphor and Analogy in the Sciences. New York: Springer.

Huggan, Graham, and Helen Tiffin. 2010. Postcolonial Ecocriticism: Literature, Animals, Environment. London: Routledge.

Iheka, Cajetan. 2018. Naturalizing Africa: Ecological Violence, Agency, and Postcolonial Resistance in African Literature. Cambridge: Cambridge University Press.

Kaschula, Russell H. 2003. "Xhosa Literary History: Towards Transformation in Selected Xhosa Novels." South African Journal of African Language 23 (2): 60-76.

Koopman, Adrian. 2015. Zulu Plant Names. Scottsville, RSA: University of KwaZuluNatal Press.

Kovecses, Zoltan. 2010. Metaphor: A Practical Introduction. Oxford: Oxford University Press.

Ladino, Jennifer. 2004. "Longing for Wonderland: Nostalgia for Nature in Postfrontier America." Iowa Journal of Cultural Studies 5 (1): 88-109.

Maathai, Wangari. 2008. Unbowed: A Memoir. New York: Knopf Doubleday.

Martin, Julia. 2017. "Natures of Africa. Ecocriticism and Animal Studies in Contemporary Cultural Forms (Fiona Moolla)." Tydskrif vir Letterkund, 54 (2): 177-80.

McGiffin, Emily. 2019. Of Land, Bones and Money: Toward a South African Ecopoetics. Charlottesville: University of Virginia Press.

Mhlophe, Gcina. 1986. Have You Seen Zandile? Portsmouth, NH: Heinemann.

Mlondo, Anthony. 1994. Meaning in D. B.Z. Ntuli's Poetry (Ph.D. dissertation). University of Zululand.

Mudimbé, Valentin-Yves. 1991. Parables and Fables: Exegesis, Textuality, and Politics in Central Africa. Madison: University of Wisconsin Press.

Murdoch, J., and T. Marsden. 1995. "The Spatialization of Politics: Local and National Actor-spaces in Environmental Conflict." Transactions of the Institute of British Geographers 20 (3): 368-80.

Nixon, Rob. 2005. "Environmentalism and Postcolonialism". In Postcolonial Studies and Beyond, edited by A. Loomba, S. Kaul, M. Bunzl, A. Burton, and J. Esty, 233-51. Durham, North Carolina: Duke University Press.

Ntuli, D. B. Z. 1972. Imvunge Yemvelo. Johannesburg, South Africa: Educum.

- 1979. Brief remarks on Zulu literature. https://disa.ukzn.ac.za/sites/ default/files/pdf_files/rejul79.4.pdf. [accessed 10 May 2020]. 
Panigrahi, Sambit. 2015. "Feminisation of Nature in Joseph Conrad's Colonial Fiction: An Ecofeminist Approach.” Literary Endeavour VI (2): 28-33.

Raum, Otto. 1973. The Social Functions of Avoidances and Taboos among the Zulu. Berlin: Walter de Gruyter.

Slaymaker, William. 2001. "Echoing the Other(s): The Call of Global Green and Black African Responses.” PMLA 116 (1): 129-44.

Slovic, Scott, Swarnalatha Rangarajan, and Vidya Sarveswaran, 2015. Ecocriticism of the Global South. New York: Lexington.

Sone, Enongene. 2010. "Aesthetics from the Swazi Perspective: The Case of the Swazi Umhlanga/Reed Dance.” Muziki 7 (1): 130-39.

Szocik, Konrad, Kateryna Lysenko-Ryba, Sylwia Banaś, and Sylwia Mazur. 2016. "Political and Legal Challenges in a Mars Colony". Space Policy 38: 27-29.

Thiong'o Ngũgĩ. 1993. Moving the Centre: The Struggle for Cultural Freedoms. Oxford: James Currey.

Van Houwelingen, Caren. 2012. "Rewriting the Plaasroman: Nostalgia, Intimacy and (Un) Homeliness in Marlene van Niekerk's Agaat." English Studies in Africa 55 (1): 93-106.

Vital, Anthony. 2005. "Situating Ecology in Recent South African Fiction:JM Coetzee's The Lives of Animals and Zakes Mda's The Heart of Redness." Journal of Southern African Studies 31 (2): 297-313.

Zulu, n.d. https://www.zulu.org.za/destinations/zululand/information/the-royalreed-dance-M57963. [Accessed 25 February 2021].

\section{Note}

1. isiZulu for 'the happiness of yesteryears'. 